\title{
KONTRIBUSI TAREKAT NAQSABANDIYAH \\ TERHADAP PENDIDIKAN AGAMA ISLAM \\ DAN PERUBAHAN PERILAKU SOSIAL \\ JAMAAH
}

\author{
(STUDI KASUS JAMAAH TAREKAT \\ NAQSABANDIYAH DI DUKUH TOMPE, \\ KABUPATEN BOYOLALI)
}

\author{
Luqman Abdullah \\ Fakultas Ilmu Tabiyah dan Keguruan, Universitas Islam Negeri Sunan \\ Kalijaga \\ Email: luqmankhit@gmail.com
}

\begin{abstract}
Luqman Abdullah, The Contribution of Tarekat Naqsabandiyah to Islamic Education and Social Behavior Change. Yogyakarta: Islamic Teaching Department of Tarbiya and Teaching Faculty UIN Sunan Kalijaga Yogyakarta.. This study aims to determine the implementation of the Tarekat Naqsabandiyah in Islamic religious education as well as the contribution of the Tarekat Naqsabandiyah towards Islamic Religious Education and changes in the social behavior of the congregation. The results showed: (1) The form of the Tarekat Naqsabandiyah Education in Tompe Hamlet is applicative yiatu gives a larger portion of the application of education from theoretical education. Coaching is done with Taubat, Suluk, Zubud and Tawakkal. In addition, in the tarekat education using the approach of remembrance, be it sirr or jabr dbiker. (2) contribution of the Tarekat Naqsabandiyah to Islamic education is: to increase the knowledge of Islam. increase faith in God., increased charity sholeh. contribution of the Tarekat Naqsabandiyah to social behavior change is: changing anxiety to calm. change the attitude of being rude to be merciful, changing the attitude of dissidents become obedient. change the attitude of shutting open.
\end{abstract}

Nazhruna: Jurnal Pendidikan Islam

Vol. 1 No 1 Maret 2018. Issn: 2614-8013. Hal. 1-18 
Keywords: Tarekat Naqsabandiyah, Islamic Education, Social Behavior

\section{Abstrak}

Luqman Abdullah, Kontribusi Tarekat Naqsabandiyah terhadap Pendidikan Agama Islam dan Perubahan Perilaku Sosial. Yogyakarta: Jurusan Pendidikan Agama Islam Fakultas Ilmu Tarbiyah dan Keguruan UIN Sunan Kalijaga Yogyakarta. Penelitian ini bertujuan untuk mengetahui pelaksanaan Tarekat Naqsabandiyah dalam pendidikan agama Islam serta kontribusi Tarekat Naqsabandiyah terbadap Pendidikan Agama Islam dan perubahan perilaku sosial jamaah. Hasil penelitian menunjukean: (1) Bentuk. Pendidikan Tarekat Naqsabandiyah di Dukub Tompe bersifat aplikatif yiatu memberikan porsi yang lebib besar pada pendidikan yang bersifat penerapan dari pendidikan teori. Pembinaan yang dilakukan adalah dengan Taubat, Suluk, Zubud dan Tawakkal. Selain itu, dalam pendidikan tarekat tersebut menggunakan pendekatan qikir, baik itu zikir sirr atau jabr. (2)Kontribusi Tarekat Naqsabandiyah terbadap pendidikan Agama Islam adalab: menambah pengetahuan Agama Islam. meningkatkan keimanan kepada Allah., meningkatan amal sholeh. Kontribusi Tarekat Naqsabandiyah terbadap perubahan perilaku sosial adalab: merubah rasa gelisah menjadi tenang. merubah sikap kasar menjadi penyayang, merubah sikap pembangkang menjadi penurut. merubah sikap menutup diri menjadi terbuka.

Kata kunci: Tarekat Naqsabandiyah, Pendidikan Agama Islam, Perilaku Sosial

\section{Pendahuluan}

Pendidikan adalah suatu aktivitas untuk mengembangkan seluruh aspek kepribadian manusia yang berjalan seumur hidup. Sedangkan pengertian Pendidikan Islam adalah pendidikan yang seluruh komponen aspeknya didasarkan pada ajaran Islam. Visi, misi, tujuan, proses belajar mengajar, pendidik, peserta didik, hubungan pendidik dan peserta didik, kurikulum, bahan ajar, sarana prasarana, pengelolaan, 
lingkungan, dan aspek atau komponen pendidikan lainnya didasarkan pada ajaran Islam ${ }^{1}$.

Pendidikan di Indonesia terbagi ke dalam tiga jalur utama, yaitu formal, nonformal, dan informal. Pendidikan nonformal adalah jalur pendidikan di luar pendidikan formal yang dapat dilaksanakan secara terstruktur dan berjenjang, seperti lembaga kursus, kelompok belajar, bahkan lembaga Tarekat. Untuk melihat pendidikan yang dilakukan oleh Tarekat atau Tasawuf, harus menilik kembali apa tujuan dari tujuan akhir pendidikan Islam itu sendiri. Karena ajaran Tarekat juga merupakan ajaran Islam yang tidak bisa terpisahkan. Jika tujuan akhir dari pendidikan Islam adalah terwujudnya manusia sebagai hamba Allah², maka Pendidikan haruslah dapat menjadikan seluruh manusia mau menghambakan diri kepada Allah SWT.

Inti dari Tarekat dalam arti ajaran adalah jalan yang harus ditempuh oleh kaum sufi dalam berusaha mendekatkan diri kepada Allah melalui ajaran-ajaran yang telah ditentukan dan dicontohkan oleh ulama-ulama sebelumnya sebagai upaya untuk penyucian hati dari sesuatu selain Allah, dan untuk menghiasi zikir kepada Allah.

Perkembangan Tarekat di Indonesia sangat pesat. Penyebarannya meliputi banyak profesi dan keahlian serta menjadi suatu idola pencapaian ketenangan batin dan ketinggian pencapaian spiritual dalam melawan hedonisme dan keterpurukan moral dan dimensi lain kehidupan manusia Indonesia saat ini ${ }^{3}$.

Penyebaran Tarekat tersebut sampai Dukuh Tompe sekitar tahun 2000, yaitu bermula dari salah seorang tokoh desa yang bernama Bp. H. Daryono yang berguru kepada Mursyid Tarekat Naqsabandiyah Prof. DR. H. Saidi Syekh Kadirun Yahya. Bp. H. Daryono berguru kepada Mursyid tersebut

${ }^{1}$ Nata Abudin, Ilmu Pendidikan Islam, 3rd ed. (Jakarta: Prenada Media Grup, 2016), 36 .

2 Heri Gunawan, Pendidikan Islam Kajian Teoritis Dan Pemikiran Islam. (Bandung: Rosdakarya, 2014), 16.

${ }^{3}$ Sri Mulyati, Peran Edukasi Tarekat Qadiriyyah Naqsyabandiyyah Dengan Referensi Utama Suralaya, Ed. 1., cet. 1 (Rawamangun, Jakarta: Kencana, 2010), vii. 
hingga pertengahan tahun 2001, kurang lebih 1,5 tahun, dikarenakan Prof. Dr. H. Kadirun Yahya telah kembali ke rahmatullah. Akan tetapi, Bp. H. Daryono masih tetap belajar dan mengamalkan ajaran tarekat tersebut. Pada awalanya Bp. H. Daryono diajak oleh saudara dari istrinya, yaitu Bp. Pardi. Penasaran atas ajakan tersebut, Bp. H. Daryono bersedia masuk ke Tarekat tersebut. Lama kelamaan istri dan keluarganya diajak masuk ke Tarekat. Bermula pada dirinya dan keluarganya, kemudian banyak tetangga beliau yang tertarik dan masuk ke Tarekat Naqsabandiyah tersebut.

Pendekatan yang dilakukan dalam Tarekat Naqsabandiyah melalui pendekatan zikir. Dengan zikir manusia akan semakin mudah untuk mendekatkan diri kepada Allah. Dan kita tahu bahwa dengan zikir pulalah seperti yang dilakukan dalam Tarekat Naqsabandiyah ini setidaknya manusia akan mendapatkan dua hal dari Allah, yaitu:

1. Orang tersebut akan selalu ditelungkupi oleh rahmat Allah

2. Orang tersebut akan selalu mendapatkan ketenangan di dalam hidupnya.

Jika manusia dalam hidupnya sudah ditelungkupi oleh rahmat Allah, sudah barang tentu akan merasakan ketenangan di dalam hidupnya. Jika demikian halnya, maka yang ada hanyalah beribadah kepada Allah dengan lebih khusuk, karena mereka sudah yakin kalau yang dapat menciptakan ketenangan hanyalah Allah. Hal ini dapat mengarahkan kepada kita untuk dapat memahami hakikat dari tujuan hidup manusia, yaitu tercapainya keselamatan hidup di dunia dan di akhirat. Dan pada akhirnya akan membuahkan perilaku sosial yang baik. Berikut ini terdapat testimoni dari jamaah Tarekat."setelah saya mengikuti terekat, banyak sekali perubahan dan manfaat yang saya peroleh. Diantaranya kenyamanan, ketentraman, hati dan pikiran tidak was-was dan khawatir tentang kehidupan, leibih bisa bersabar dalam menyikapi masalah." (testimoni Bp. Joko Maskuri) "Intinya, setelah saya mengikuti Tarekat Naqsabandiyah, hatinya lebih tenang, damai dan tentram. Dalam bertindak lebih berhati-hati, dan perilaku apapun lebih 
baik. Selain itu dalam beribadah ya lebih khusuk dari pada sebelum masuk Tarekat"' (Testimoni oleh Bapak Sunarno)

Dari beberapa testimoni di atas, bisa disimpulkan bahwa sebelum mereka masuk Tarekat, mereka mengalami kondisi batin yang kurang tenang dan kurang stabil, sehingga mengakibatkan perilaku sosialnya kurang baik. Akan tetapi setelah masuk dan mengamalkan serta mendapat bimbingan dalam Tarekat seperti Taubat, Suluk, Zuhud selama beberapa tahun, kondisi batin dan kejiwaan mereka secara bertahap berubah kearah yang lebih positif, seperti hati dan pikiran tidak was-was, damai, dan tenang. Selain itu dalam bertindak dan berperilaku mereka selalu berhati-hati, karena mereka merasa dirinya selalu diawasi oleh Allah. Setelah melihat beberapa testimoni tersebut diduga terdapat kontribusi positif Tarekat Naqsabandiyah terhadap Pendidikan Agama Islam dan perubahan perilaku sosial.

Oleh karena itu, jika dilihat dari latar belakang di atas, penulis tertarik untuk melakukan penelitian mengenai "Kontribusi Tarekat Naqsabandiyah Terhadap Pendidikan Agama Islam Dan Perubahan Perilaku Sosial (Studi Kasus Jamaah Tarekat Naqsabandiyah Di Dukuh Tompe Kelurahan Karangnongko Kecamatan Mojosongo Kabupaten Boyolali)”

Pertanyaan yang akan dijawab dalam penelitian ini adalah yang akan dijawab dalam penelitian ini adalah Bagaimanakah pelaksanaan Tarekat Naqsabandiyah dalam pendidikan agama Islam di Dukuh Tompe Kelurahan Karangnongko Kecamatan Mojosongo Kabupaten Boyolali? dan bagaimanakah kontribusi Tarekat Naqsabandiyah terhadap Pendidikan Agama Islam dan perubahan perilaku sosial jamaah di Dukuh Tompe Kelurahan Karangnongko Kecamatan Mojosongo Kabupaten Boyolali?

\section{Kajian Teori}

\section{Tarekat Naqsabandiyah}

Pengertian Tarekat menurut Syekh Amin al-Kurdi bahwa Tarekat itu berarti menjauhkan diri dari segala yang 
dilarang syara', zahir maupun batin dan mengikuti segala perintah dari Allah yang diusahakan dengan sekuat tenaga yang ada pada masing-masing kita. Sedangkan "Naqsyabandiyab" menurut Syekh Najmudin Amin Al-Kurdi dalam kitabnya "tanwirul qulub" sebagaimana yang dikutip oleh Fuad Said, berasal dari dua buah kata bahasa Arab, "Naqsy" dan "band" artinya "ukiran atau gambar yang dicap pada sebatang lilin atau benda lainnya". Dan “Band" artinya "Bendera atau layar lebar". Jadi "Naqsabandi" artinya ukiran atau gambar yang terlukis pada suatu benda, melekat, tidak terpisah lagi, seperti tertera pada sebuah bendera atau sepanduk. Dinamakan dengan "Naqsyaqbandiyab", karena Syekh Bahaudin pendiri tarekat ini senantiasa berzikir mengingat Allah berkepanjangan, sehingga lafadz "Allah" itu terukir melekat ketat dalam kalbunya".

Dalam sebuah organisasi tarekat, terdapat sejumlah komponen yang meliputi:

\section{Guru Tarekat atau Mursyid}

Kedudukan Mursyid dalam suatu tarekat menempati posisi penting dan menentukan. Seorang Mursyid bukan hanya memimpin, membimbing dan membina muridmuridnya dalam kehidupan lahiriah dan pergaulan sehari-hari supaya tidak menyimpang dari ajaran-ajaran Islam dan terjerumus ke dalam maksiat seperti berbuat dosa besar atau dosa kecil. Tetapi juga membimbing, memimpin, dan membina muridn-muridnya melaksanakan kewajiban yang ditetapkan oleh agama dan melaksanakan amal sunnah untuk mendekatkan diri kepada Allah SWT ${ }^{5}$.

\section{Murid}

Murid adalah pengikut atau pengamal dari suatu tarekat. Seorang kandidat murid disyaratkan harus berjanji setia kepada dirinya dihadapan Mursyid bahwa ia akan mengamalkan segala bentuk amalan dan wirid yang telah 2007), 7 .

${ }^{4}$ Fuad Said H.A, Hakikat Tarekat Naqsabandiyah (Jakarta: Pustaka Al Husna,

5 Djamaan Nur, Tasawuf Dan Tarekat Naqsabandiyah Pimpinan Prof. Kadirun Yahya (Medan: USU Press, 2002), 5. 
dianjurkan Mursyid kepadanya dengan sungguh-sungguh. Janji setia ini dikenal dengan istilah bai'at.

\section{Amalan dan wirid tarekat}

Salah satu amalan utama yang menjadi wirid Tarekat adalah zikir. Kata zikir dari segi bahasa berasal dari kata

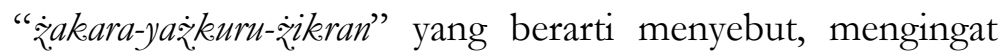
dan memberi nasihat. Praktik zikir dalam dunia tarekat, pelaksanaannya bisa berbeda-beda dan dalam teknisnya tergantung ciri dan kepribadian Tarekat itu sendiri sesuai petunjuk mursyidnya.

Ulama tarekat membagi jenis zikir menjadi tiga jenjang : 1) Zikir lisan : Là Iläha Illallah. Mula-mula pelan kemudian bisa naik menjadi cepat setelah merasa meresap dalam di hati. 2) Zikir qalbu (hati) : Allah, Allah. Mula-mula mulut berzikir diikuti oleh hati, kemudian dari hati ke mulut, lalu lidah berzikir sendiri, dengan zikir tanpa sadar, akal pikiran tidak jalan lagi, melainkan terjadi sebagai ilham yang menjelma Nur Ilahi dalam hati. 3) Zikir Sir atau Rahasia : Hu $H u$. Biasanya sebelum sampai ke tingkat zikir orang itu sudah fana lebih dahulu. Dalam situasi yang demikian perasaan antara diri dengan Dia menjadi satu. Man lam jazuk lam ya'rif: Barang siapa belum merasakan, maka ia belum mengetahui ${ }^{7}$.

\section{Zawiyah tarekat}

Zawiyah adalah mejelis tempat para salik mengamalkan suluk, dzikir, dan berbagai wirid tarekat yang lain. Seperti membaca manqib Syekh Abdul Qadir al-Jailani dan membaca Ratib Syekh Muhammad Saman. Latar belakang munculnya zawiyah tidak lepas dari kebiasaan kaum sufi dalam mengembara dari satu tempat ke tempat yang lain. Mereka berwatak kosmopolitan dalam mencari pimbimbing rohani, tanpa terikat oleh batas-batas teritorial suatu Negara.

${ }^{6}$ A.W. Munawwir, A. Ma'shum, and Z.A. Munawwir, Al-Munawwir: Kamus Arab-Indonesia Terlengkap (Pustaka Progressif, 1997), 396, https://books.google.co.id/books?id=N2ojywAACAAJ.

${ }^{7}$ Mustofa Zahri, Kunci Memahami Ilmu Tasawuf, Cet. 1 (Surabaya: Bina Ilmu, 1993), 65 . 


\section{Pendidikan Agama Islam}

Pendidikan islam adalah pendidikan yang seluruh komponen aspeknya didasarkan pada ajaran Islam. Visi, misi, tujuan, proses belajar mengajar, pendidik, peserta didik, hubungan pendidik dan peserta didik, kurikulum, bahan ajar, sarana prasarana, pengelolaan, lingkungan dan aspek atau komponen pendidikan lainnya di dasarkan pada ajaran Islam ${ }^{8}$.

Pada hakekatnya tujuan pendidikan Islam berfokus pada tiga bagian. Pertama, terbentuknya Insan al-Kämil (manusia paripurna) yang memiliki akhlak qur'ani. Tahapan untuk memperoleh Insan al-Kamil itu diperoleh melalui ketaatan terhadap hukum-hukum Allah SWT, sebagai bentuk tertinggi dalam kesadaran diri tentang pribadi dan tugas-tugas kekhalifahan Ilahi'.

\section{Perilaku Sosial}

Menurut Elizabet B. Hurlock ${ }^{10}$, Perilaku sosial adalah aktifitas fisik dan psikis seseorang terhadap orang lain atau sebaliknya dalam rangka memenuhi diri atau orang lain yang sesuai dengan tuntutan sosial.

Berbagai bentuk dan jenis perilaku sosial seseorang pada dasarnya merupakan karakter atau ciri kepribadian yang dapat teramati ketika seseorang berinteraksi dengan orang lain. Seperti dalam kehidupan berkelompok, kecenderungan perilaku sosial seseorang yang menjadi anggota kelompok akan terlihat jelas diantara anggota kelompok yang lainnya.

Baron dan Byrne berpendapat bahwa ada empat kategori utama yang dapat membentuk perilaku sosial seseorang, yaitu: 1) Perilaku dan karakteristik orang lain. 2) Proses Kognitif. 3) Faktor Lingkungan. 4) Tatar budaya sebagai tempat perilaku dan pemikiran sosial itu terjadi.

${ }^{8}$ Abudin, Ilmu Pendidikan, 36.

${ }^{9}$ Gunawan, Pendidikean Islam, 15-16.

${ }^{10}$ Elizabeth B Hurlock, Developmental Psychology: A Life-Span Approach (New Delhi: Tata McGraw-Hill, 1981), 262. 
Nazhruna: Jurnal Pendidikan Islam

Krech $^{11}$ mengungkapkan bahwa untuk memahami perilaku sosial individu, dapat dilihat dari kecenderungankecenderungan ciri-ciri respon interpersonalnya. Pertama, Kecenderungan Peranan (Role Disposition); yaitu kecenderungan yang mengacu kepada tugas, kewajiban dan posisi yang dimiliki seorang individu. Kedua, Kecenderungan Sosiometrik (Sociometric Disposition); yaitu kecenderungan yang bertautan dengan kesukaan, kepercayaan terhadap individu lain. Ketiga, Ekspressi (Expression Disposition), yaitu kecenderungan yang bertautan dengan ekpresi diri dengan menampilkan kebiasaaan-kebiasaan khas (particular fashion).

\section{Metode Penelitian}

Jenis penelitian ini adalah penelitian kualitatif yang memanfaatkan paradigma penelitian interpretatif dengan tujuan membengun makna berdasarkan data-data lapangan. Adapun pendekatan yang digunakan dalam penelitian kualitatif ini adalah pendekatan antropologi. Pendekatan antropologi dapat diartikan sebagai suatu sudut pandang atau cara melihat dan memperlakukan sesuatu gejala yang menjadi perhatian terkait bentuk fisik dan kebudayaan sebagai hasil dari cipta, karsa dan rasa manusia.

Subjek dalam penelitian ini adalah pengikut Tarekat Naqsabandiyah di Dukuh Tompe. Penentuan subjek dilakukan dengan menggunakan teknik purposive sampling, adalah teknik penentuan informan dengan pertimbangan tertentu.

Pengumpulan data menggunakan metode wawancara, observasi, dan dokumentasi. Wawancara adalah percakapan dengan maksud tertentu. Percakapan itu dilakukan oleh dua pihak, yaitu pewawancara yang mengajukan pertanyaan dan terwawancara yang memberikan jawaban atas pertanyaan $\mathrm{itu}^{12}$. Adapun jenis wawancara yang digunakan adalah wawancara tidak tersetruktur. Observasi adalah suatu cara untuk

${ }^{11}$ David Krech, Egerton L Ballachey, and Richard S Crutchfield, Individual in Society: A Textbook of Social Psychology. (New York: McGraw-Hill, 1975), 106.

12 Moloeng Lexy J, Metodologi penelitian Kualitatif, 29th ed. (Bandung: Rosdakarya, 2011), 186. 
mengadakan penilaian dengan jalan mengadakan pengamatan secara langsung dan sistematis. Data-data yang diperoleh dalam observasi itu dicatat dalam suatu catatan observasi.

Dokumentasi merupakan suatu teknik pengumpulan data dengan menghimpun dan menganalisis dokumen-dokumen tertulis, gambar maupun elektronik. Metode dokumentasi yaitu mencari data mengenai hal-hal atau variabel yang berupa catatan, transkip, buku, surat kabar, majalah, prsasati, notulen, dan sebagainya ${ }^{13}$.

Untuk menganalisi data yang diperoleh, penulis menggunakan analisis deskriptif yang dikembangkan oleh Milles dan Hubberman ${ }^{14}$ dengan tiga langkah:

1. Reduktsi data

Reduksi data merepakan kegiatan pemilihan, penyederhanaan dan transformasi data kasar yang muncul dari catatan tertulis di lapangan sehingga lebih fokus sesuai dengan obyek penelitian.

2. Penyajian data

Dengan penyajian data dari sekumpulan informasi akan memberikan kemungkinan adanya penarikan kesimpulan dan pengambilan tindakan

3. Penarikan kesimpulan

Dari hasil pengolahan dan penganalisisan data ini kemudian diberikan interpretasi yang akhirnya digunakan oleh penulis sebagai dasar untuk menarik kesimpulan.

\section{Pembahasan}

\section{Pelaksanaan Tarekat Naqsabandiyah dalam pendidikan agama Islam}

Setiap bentuk pendidikan memiliki karakteristik tersendiri sesuai dengan misi yang diembannya. Demikian juga pendidikan tarekat, ia memiliki karakteristik khas berdasarkan

13 Arikunto Suharsimi, Metode Penelitian Pendidikan dan Pengembangan, 5th ed. (Jakarta: Kencana, 2016), 3.

${ }^{14}$ Matthew B. Miles, A. M. Huberman, and Johnny Saldaña, Qualitative Data Analysis: A Methods Sourcebook, Third edition (Thousand Oaks, Califorinia: SAGE Publications, Inc, 2014). 
landasan dasar yang dianutnya. Karakteristik pendidikan Tarekat Naqsabandiyah di Dukuh Tompe bersifat aplikatif. Bersifat aplikatif di sini maksudnya memberikan porsi yang lebih besar pada pendidikan yang bersifat penerapan dari pendidikan teori.

Ada beberapa hal yang membingkai karaktersitik pendidikan aplikatif yang dilaksanakan dalam jamaah Tarekat Naqsabandiyah di dukuh Tompe. Pertama, mendahulukan pengamalan dan pengalaman dari pengetahuan. pendidikan yang diterapkan dalam Tarekat Naqsabandiyah ini bersifat aplikatif, yaitu pendidikan yang menekankan pada pengamalan dan pengamalan terlebih dahulu dari pengetahuan. Hingga sekarang pendidikan yang aplikatif ini masih diteruskan oleh para Badal Mursyid. Para Badal Mursyid selalu menekankan para murid untuk melaksanakan ajaran terlebih dahulu, hingga ia menemukan hikmah dari ajaran yang diamalakannya itu. Misalnya dalam menjalankan suatu latihan zikir yang harus dikerjakan pada waktu tertentu, seorang murid tidak perlu banyak bertanya tentang apa maksudnya atau apa landasannya, ia hanya harus melaksanakannya secara konsisten sehingga kelak akan menemukan jawabannya sendiri.

Kedua, pendidikan Adab. Pendidikan dalam jamaah Tarekat Naqsabandiyah adalah pendidikan adab. Sejuah mana murid menjalankan Tarekatnya berbanding lurus dengan sejauh mana ia melaksanakan adab.

Adab adalah panduan gerak (jasmani), fikir, rasa, watak dan keyakinan murid dalam hubungannya dengan Allah, Guru, dan sesama murid. Adab adalah praktik kehidupan yang berittiba' pada sunnah Nabi dan perilaku salaf al-șalibin. Sehingga dapat dikatakan bahwa pendidikan Tarekat Naqsabandiyah adalah pendidikan adab yang maksudnya pendidikan praktik kehidupa yang beittiba' pada sunnah Nabi SAW dan prilaku salaf al-saliHin.

Dalam mengatur gerak jasmani, misalnya, terdapat adab tentang bagaimana cara berjalan dan duduk bagi murid Tarekat Naqsabandiyah. Adab tersebut dinamakan nazar bar qadam yang berarti melihat telapak kaki. Seorang murid berjalan dengan melihat tempat yang akan dilangkahi oleh kakinya. Demikian 
halnya dengan tata cara duduk bagi murid. Terdapat aturan tersendiri tentang tata cara duduk secara umum, ketika berzikir, ketika duduk bersama Guru, dan ketika bersama teman.

Ada beberapa proses pembinaan yang dilakukan dalam tarekat Naqsabandiyah ini, pertama Taubat, Taubat adalah dasar utama untuk membersihkan diri dari dosa lahir maupun batin. Dengan pembersihan diri dari kesalahan dan sifat-sifat tercela maka hijab-hijab yang membatasi diri dengan khaliq akan segera terkuak.

Kedua adalah Suluk, Suluk berarti menempuh jalan menuju kepada Allah SWT. Suluk juga disebut khalwat, yaitu berada ditempat yang sunyi sepi, agar dapat beribadah dengan khusyuk dan sempurna.

Jamaah tarekat yang berasal dari Dukuh Tompe biasanya mingikuti suluk di Surau Haqqul Amin Karanganyar, di Surau Nurul Amin Surabaya dan di Surau Qutubul Amin Depok. Dalam suluk, seorang murid diajarkan berbagai pelajaran zikir dan mendapatkan ijazah zikir dari Mursyid

Pembinaan yang ketiga adalah zuhud, Maksud dari zuhud bukanlah semata-mata tidak mau memiliki harta dan tidak suka mengenyam kenikmatan dunia, tetapi hakikat zuhud yang sebenarnya adalah kondisi mental yang tidak mau terpengaruh oleh harta dan kesenangan duniawi dalam mengabdikan diri kepada Allah SWT.

Pembinaan Zuhud dalam Tarekat Naqsabandiyah melalui sedekah, setiap murid diwajibkan untuk selalu bersedekat setiap hari dan sedekahnya harus menggunakan uang. Hal ini bertujuan agar murid tersebut tidak cinta dengan dunia, akan tetapi meletakkan dunia di dalam genggamannya.

Pembinaan yang keempat adalah Tawakal, yaitu menyerahkan segala perkara, ikhtiar dan usaha yang dilakukan, kepada Allah SWT serta berserah diri sepenuhnya kepada-Nya guna mendapatkan manfaat atau menolak mudharat.

Pembinaan tawakkal jamaah dalam Tarekat Naqsabandiyah di dukuh Tompe ini disampaikan melalui dua cara. Pertama, yaitu dengan tausiyah setelah khatam tawajuh. 
Selain itu juga melalui bimbingan langsung antara murid dengan Badal Mursyid.

Pendekatan Pendidikan yang dilakukan dalam Tarekat Naqsabandiyah ini melalui zikir. Kata zikir dari segi bahasa

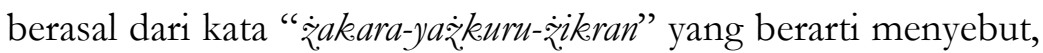
mengingat dan memberi nasihat.

Dalam Tarekat Naqsabandiyah ini ada beberapa mata pelajaran Zikir.

Zikir Ismu Zat, yaitu zikir dengan meyebut nama zat Allah yaitu Allah, Allah, Allah... bagi orang yang baru masuk Tarekat, zikir Ismu Zat ini diamalkan 5000 kali dalam sehari semalam. Tujuan dari qikir Ismu Zat adalah utnuk menanamkan Allah dalam hati.

Zikir Lațaif, yaitu Zikir Ismu Zat sebanyak 11000 yang berhikmah menghancurkan sifat Madzmumah yang ada pada batin manusia, yang sekaligus sebagai sarang iblis. Tujuh tempat sifat Madzmumah itu jika dibersihkan dari sifat-sifat buruknya, maka akan ada yang akan menggantikannya adalah sifat Mahmudah.

Zikir Nafi Isbat ini diajarkan setelah menerima pelajaran zikir Lataif, pelajarannya dilaksankan ketika Suluk. Zikir Nafi Isbat adalah pelajaran untuk menafikan Tuhan, ketika dia berzikir dia yang ada hanya Allah, semua hilang. Ketika dicoba dibangunkan dari zikirnya, dia pasti akan menyebut Allah, karena semuanya hilang selain Allah.

Zikir muraqabah ialah berkekalannya seorang hamba ingat bahwa dirinya senantiasa dimonitor oleh Tuhannya dalam seluruh keadaan tingkah lakunya.

Zikir Wukuf adalah zikir diam dengan semata-mata mengingat Allah, yaitu mengingat zat Allah yang bersifat dengan segala sifat sempurna dan suci atau jauh dari segala sifat kekurangan. Zikir wukuf ini dirangkiakan setelah selesai melaksanakan zikir Ismu Zat atau rikir Lațaif atau rikir Nafi Isbat.

Zikir Maqomat, Seorang murid berzikir sesuai dengan maqamnya. Maqam menunjuk kepada keberadaan seseorang di 
jalan Allah dan dipenuhi olehnya kewajiban-kewajiban yang berkaitan dengan maqam itu dan penjagaannya atas itu. Maqam pertamya adalah taubat, kemudian menyusul berubah sikap, kemudian zuhud, lalu tawakkal kepada Tuhan, dan seterusnya.

Zikir tahlil lisan ialah melaksanakan zikir Nafi Isbat yang diucapkan secara kedengaran atau jahar. Zikir ini dilaksanakan pada waktu-waktu yang telah ditetapkan Syekh Mursyid. Pelaksanaannya dilakukan secara berjamaah dengan Syekh Mursyid atau dengan Badal Mursyid.

Khatam Tawajuh. Bagi pengamal Tarekat Naqsabandiyah, Khatam Tawajuh ini merupakan peramalan pokok. Dalam Khatam tersebut membaca surat al-Fatihah 7 kali, Shalawat 100 kali, surat al-Insyirah 79 kali, surat al-Ikhlas 1001 kali, surat al-Fatihah 7 kali, shalawat 100 kali. Tawajuh berarti menyatukan atau mengkonsentrasikan seluruh indra zahir dan batin untuk munajat, berzikir ke hadirat Allah SWT. Khatam Tawajuh ini bisa dilakukan sendiri-sendiri dan bisa berjamaah

\section{Kontribusi Tarekat Naqsabandiyah terhadap Pendidikan Agama Islam dan Peribahan Perilaku Sosial}

Berdasarkan data hasil wawancara dan observasi terhadap jamaah Tarekat Naqsabandiyah di dukuh Tompe, Tarekat Naqsabandiyah ternyata memberikan kontribusi besar dalam Pendidikan Agama Islam dan perubahan perilaku sosial.

Data hasil wawancara tersebut menunjukkan bahwa para jamaah / pengikut Tarekat Naqsabandiyah sebelumnya merupakan orang-orang biasa seperti pada umumnya, mayoritas masih awam dengan ilmu agama, minim dalam pelaksanaan praktik-praktik ibadah baik ibadah khusus maupun ibadah umum. Mayoritas juga memiliki perilaku sosial yang kurang baik dan bahkan banyak sekali yang bersifat temperamental, merasa tidak tenang dan tidak mampu mengedalikan emosinya.

Setelah mengikuti Tarekat Naqsabandiyah, banyak sekali perubahan-perubahan yang dirasakan oleh jamaah Tarekat Naqsabandiyah. Meraka menjadi lebih tekun beribadah, baik 
yang ibadah wajib maupun sunah, perilaku kesehariannya terhadap keluraga maupun masyarakat sekitar menjadi lebih baik, lebih sabar dan tidak lagi temperamental. Semakin gemar dan giat menuntut ilmu (ilmu-ilmu Agama), juga tetap bersemangat dan seimbang dalam memenuhi kebutuhan dunia akhirat.

Perubahan sifat dan sikap menuju ke arah yang semakin baik, baik dari segi pengetahuan agama, akhlak, ibadah, keimanan, ketenangan ruhaniah/mental merupakan indikasi adanya kontribusi Tarekat Naqsabandiyah terhadap Pendidikan Agama Islam dan perilaku sosial.

a. Kontribusi tarekat naqsabandiyah terhadap Pendidikan Agama Islam:

1) Menambah pengetahuan Agama Islam. Dari data hasil wawancara menunjukkan bahwa kelima narasumber sebelum mengikuti Tarekat Naqsabandiyah memiliki pengetahuan Agama Islam yang kurang, akan tetapi setelah mengikuti Tarekat Naqsabandiyah mereka mengaku memperoleh pengetahuan keislaman. Materi yang disampaikan tidak hanya berupa tentang ilmu syariat saja, akan tetapi juga bagaimana harus menjalani hidup ini.

2) Meningkatkan keimanan kepada Allah. Salah satu tujuan dari Tarekat Naqsabandiyah adalah untuk meningkatkan keimanan para pengikutya. Beberapa cara atau metode yang telah dilaksanakan untuk tujuan tersebut adalah dengan pengamalan zikir sebagai amalan rutin baik secara individu maupun secara berjamaah dan pelajaran bersifat dalil-dalil ataupun berupa pembiasaan amal-amal yang mengarah pada penanaman keimanan.

3) Meningkatkan amah sholeh. Salah satu tujuan dari Tarekat Naqsabandiyah adalah untuk meningkatkan keimanan para pengikutya. Beberapa cara atau metode yang telah dilaksanakan untuk tujuan 
tersebut adalah dengan pengamalan zikir sebagai amalan rutin baik secara individu maupun secara berjamaah dan pelajaran bersifat dalil-dalil ataupun berupa pembiasaan amal-amal yang mengarah pada penanaman keimanan.

b. Kontribusi Tarekat Naqsabandiyah terhadap perubahan perilaku sosial

1) Merubah rasa gelisah menjadi tenang. sebelum masuk Tarekat Naqsabandiyah jamaah mengalami keadaan batin yang selalu gelisah dengan hidupnya, takut jika kebutuhan kesehariannya tidak terpenuhi. Akan tetapi setelah mengikuti Tarekat Naqsabandiyah beliau mengalami perubahan menjadi lebih tenang. Seperti ketika beliau menjual sapi yang tak kunjung dibayar. Beliau mengahadapi masalah tersebut dengan tenang.

2) Merubah sikap kasar menjadi penyayang. Jamaah yang bernama Bp. Narno sebelum mengikuti Tarekat Naqsabandiyah beliau memiliki sikap pemarah dan keras kepala terhadap semua orang bahkan kepada keularganya. Sikap kasar ini disebabakan karena beliau memiliki temperamental yang tinggi sehingga menyebabkan beliau tidak mau mengalah kepada semua orang. Temparamental yang tinggi ini juga menjadi salah satu penyebab rumah tangga beliau mengalami perceraian. Akan tetapi setelah beliau mengikuti Tarekat Naqsabandiyah, sikap kasar dan pemarah beliau sedikit demi sedikut berkurang dan berubah menjadi sikap yang penyayang. selain itu sikap yang tidak mau mengalah juga sedikit demi sedikit menghilang. Sekarang beliau memiliki kehidupan rumah tangga yang baru dan kehidupan keluarganya yang sekarang lebih harmonis jika dibandingkan dengan kehidupan keluarganya dulu sebelum mengkuti Tarekat Naqsabandiyah. 
3) Merubah sikap pembangkang menjadi penurut. Jamaah yang bernama Ibu Budy Mahmudah dan Ibu Murniyati sebelum mengikuti Tarekat Naqsabandiyah kurang patuh terhadap suami mereka. Seperti yang terjadi pada Ibu Murniyati, sebelum dia masuk Tarekat Naqsabandiyah, beliau selalu menjawab nasehat dan arahan suaminya dan sering menolak nasehat tersebut. Akan tetapi setelah mengikuti Tarekat Naqsabandiyah selama 5 tahun, sifat tersebut berubah dan menjadi penurut serta mau menerima nasehat dari suaminya.

4) Merubah sikap menutup diri menjadi terbuka. Dari data hasil wawancara menunjukkan bahwa sebelum mengikuti Tarekat Naqsabandiyah, Bapak Narno jarang keluar rumah dan lebih sering menutup diri. Bahkan juga jarang mengikuti kerja bakti di masyarakat. Begitu juga yang dialami oleh Ibu Khoirun Nisa, mereka selalu menutup diri dan tidak mau berbaur dengan masyarakat sekitar, seperti tidak saling tegur sapa, jarang keluar rumah. Akan tetapi setelah mengikuti Tarekat Naqsabandiyah, mereka mengalami perubahan menjadi suka bergaul dengan tetangga, menolong tetangga yang kesusahan dan sikapnya kepada orang lain semakin baik.

\section{Simpulan}

Berdasarkan uraian dan analisis yang telah dipaparkan, maka dapat diambil kesimpulan sebagai berikut:

Pertama, Bentuk Pendidikan Tarekat Naqsabandiyah di Dukuh Tompe bersifat aplikatif. Bersifat aplikatif di sini maksudnya memberikan porsi yang lebih besar pada pendidikan yang bersifat penerapan dari pendidikan teori. Pembinaan yang dilakukan adalah dengan Taubat, Suluk, Zuhud dan Tawakkal. Selain itu, dalam pendidikan tarekat tersebut menggunakan pendekatan zikir, baik itu zikir sirr atau jahr. 
Kedua, Kontribusi Tarekat Naqsabandiyah terhadap pendidikan Agama Islam dan perubahan perilaku sosial jamaah di Dukuh Tompe adalah sebagai berikut: (1) Kontribusi Tarekat Naqsabandiyah terhadap pendidikan Agama Islam adalah: (a) Menambah pengetahuan Agama Islam. (b) Meningkatkan keimanan kepada Allah. (c) Meningkatan amal sholeh. Kontribusi Tarekat Naqsabandiyah terhadap perubahan perilaku sosial adalah: (a) Merubah rasa gelisah menjadi tenang. (b) Merubah sikap kasar menjadi penyayang. (c) Merubah sikap pembangkang menjadi penurut. (d) Merubah sikap menutup diri menjadi terbuka.

\section{Saran}

Berdasarkan pembahasan dan analisa pada bab sebelumnya maka dapat diperoleh kesimpulan sebagai berikut:

Pertama, Bagi seluruh pengurus Tarekat Naqsabandiyah di Dukuh Tompe, harus mampu memberikan pemahaman yang benar bagi masyarakat mengenai Tarekat, sehingga hal-hal tersebut tidak lagi menjadi penghambat dalam syiar Tarekat Naqsabandiyah.

Kedua, Bagi seluruh jamaah Tarekat Naqsabandiyah, seharusnya melaksanakan amalan dan ajaran Tarekat (baik yang sifatnya individual maupun berjamaah) secara rutin dan terusmenerus.

Ketiga, Bagi sekolah-sekolah dan lembaga pendidikan lainnya, sebaiknya menambahkan kegiatan pendidikan Tarekat seperti zikir, sehingga tercipta ketenangan batin dalam diri siswa dan menjadi mudah dalam memahami pelajaran maupun dalam pembentukan perilaku sosial yang baik. Selain itu, dalam penyampaian materi pelajaran PAI bisa pula ditambah dengan makna yang mendalam bagi kehidupan, seperti dalam pendidikan tarekat yang sarat dengan nilai dan makna seningga implikasinya bukan hanya pada pelaksanaan syariat Islam, namun pemaknaan syariat Islam secara mendalam yang pada akhirnya terbentuk akhlak karimah dan kepribadian muslim dalam diri siswa. 
Nazhruna: Jurnal Pendidikan Islam

\section{DAFTAR PUSTAKA}

Abudin, Nata. Ilmu Pendidikan Islam. 3rd ed. Jakarta: Prenada Media Grup, 2016.

Gunawan, Heri. Pendidikan Islam Kajian Teoritis Dan Pemikiran Islam. Bandung: Rosdakarya, 2014.

H.A, Fuad Said. Hakikat Tarekat Naqsabandiyah. Jakarta: Pustaka Al Husna, 2007.

Hurlock, Elizabeth B. Developmental Psychology: A Life-Span Approach. New Delhi: Tata McGraw-Hill, 1981.

Krech, David, Egerton L Ballachey, and Richard S Crutchfield. Individual in Society: A Textbook of Social Psychology. New York: McGraw-Hill, 1975.

Lexy J, Moloeng. Metodologi penelitian Kualitatif. 29th ed. Bandung: Rosdakarya, 2011.

Miles, Matthew B., A. M. Huberman, and Johnny Saldaña. Qualitative Data Analysis: A Methods Sourcebook. Third edition. Thousand Oaks, Califorinia: SAGE Publications, Inc, 2014.

Munawwir, A.W., A. Ma' shum, and Z.A. Munawwir. Al-Munawwir: Kamus Arab-Indonesia Terlengkap. Pustaka Progressif, 1997. https://books.google.co.id/books?id=N2ojywAACAAJ.

Nur, Djamaan. Tasawuf Dan Tarekat Naqsabandiyah Pimpinan Prof. Kadirun Yabya. Medan: USU Press, 2002.

Sri Mulyati. Peran Edukasi Tarekat Qadiriyyah Naqsyabandiyyah Dengan Referensi Utama Suralaya. Ed. 1., cet. 1. Rawamangun, Jakarta: Kencana, 2010.

Suharsimi, Arikunto. Metode Penelitian Pendidikan dan Pengembangan. 5th ed. Jakarta: Kencana, 2016.

Zahri, Mustofa. Kunci Memahami Ilmu Tasawuf. Cet. 1. Surabaya: Bina Ilmu, 1993. 
